\title{
Dendritic Cells as an Adjuvant to some Schistosoma mansoni Antigens for Vaccination in Experimental Schistosomiasis
}

\author{
Amany F. Atia*, Amera F. Afifi, Mohammed M. Abdel Gaffer, Nadia S. ELNahas, \\ Mona F. Abdel-Samee Faheem and Salwa F. A. Oshiba \\ Department of Medical Parasitology, Faculty of Medicine, Menoufia University, Egypt \\ *Corresponding author
}

\section{A B S T R A C T}

\section{Keywords}

Dendritic cells, Vaccination, Adjuvant, Schistosoma mansoni antigens, Experimental Schistosomiasis

\section{Article Info}

Accepted: 05 February 2020 Available Online: 10 March 2020
Schistosomiasis is a major disease of the developing world. Despite integrated control measures, schistosomiasis continues to spread to new regions. So, there is a pressing need to identify new antigens and to explore new adjuvants to improve vaccine efficacy. The aim of the present study was to evaluate the efficacy of an adjuvant dendritic cell (DC) combined with $S$. mansoni SEA and SWAP antigens as vaccination in mice experimentally infected with S. mansoni. The study was carried out on 70 laboratory bred Swiss albino male mice. The mice were divided into seven groups each contained 10 mice. The vaccine was given in three doses injected subcutaneously at two weeks' interval. Porto-mesenteric worm burden, hepatic and intestinal egg counts, hepatic granuloma number and diameter, and oogram pattern were assessed to evaluate the antischistosomal effect of vaccines. Ig G, IL-10 \& IL-12p40 levels were tested to assess immunological effect. Results revealed that the use of SEA + DCs were associated with a significant decrease in worm burden and tissue egg load together with an increased percentage of dead eggs. In addition, there was a significant reduction in granuloma formation. Also percent of CD4 +ve cells in liver and IL-10 \& IL 12p40was the highest in SEA+DCs group. Importantly, our data suggest a need to re-evaluate host immune responses to many schistosome antigens. There is also a need for a standardized \& effective adjuvant formulation and schistosomiasis vaccine development.

\section{Introduction}

Schistosomiasis is the second-most widespread human parasitic disease after malaria (Duval et al., 2015). It is estimated that nearly 258 million people are infected worldwide with up to 700 million at risk of being infected, leading to an estimated 280000 deaths annually (WHO, 2017; Toor et al., 2018). The antischistosomal praziquantel
(PZQ) is cheap, effective and widely available, but drug fails to treat all cases and does not prevent reinfection. Thus, in spite of the wide-scale use of PZQ in the past 40 years, the numbers of infected individuals, especially in sub-Saharan Africa, remain at an unsatisfactorily high level (Hagan et al., 2004). Many consider that the best long-term strategy to control schistosomiasis is through immunization combined with drug treatment 
(Bergquist, 2002; Morais et al., 2018). The development of a protective vaccine against schistosomiasis still remains potentially the most effective mean for controlling the disease (Merrifield et al., 2016). The current Schistosoma vaccine candidates prove not to be the most effective, so it is important to identify new antigens and to explore alternative vaccination strategies, including new adjuvants to improve vaccine efficacy (McManus and Loukas, 2008). Adjuvant selection has a large impact on the effectiveness of the vaccine, and the use of adjuvants to aid in the stimulation of the immune system is a critical step and a major variable affecting vaccine development (Stephenson et al., 2014).

Soluble egg antigen (SEA) coming from seeded eggs in liver tissue activates Th1polarized response (Pearce, 2005), while $S$. mansoni adult worm antigen (SWAP) modulates the effects of Th1 and Th2 responses through immunosuppressive cytokines as interleukin- 10 (IL-10) and transforming growth factor beta (TGF-b). The balance between Th1, Th2 determines the outcome of Schistosoma infections (Milner et al., 2010). Dendritic cells (DCs) are specialized antigen-presenting cells that play a central role in cellular immunity and immunotolerance (Boeckh and Ljungman, 2009). DCs are critical in the activation of $T$ cells, providing antigen presentation, costimulatory signals, and inflammatory cytokine stimulation to direct an effector $\mathrm{T}$ cell response (Constantino et al., 2017). DCs are activated and acquire an inflammatory profile and have the ability to direct the profile of helper $\mathrm{T}$ (Th) cells towards $\mathrm{Th} 1$, Th2, Th17, Th9 and regulatory (Treg) cells (Perona, 2018). DCs facilitate cross talk between the innate and adaptive immune system. Targeting vaccines to DCs thus provides a great deal of opportunities for influencing the humoral immune responses, by fine-tuning the $\mathrm{T}$ cell response as well as regulating antigen availability for B cells (Tesfaye, 2019). DCs vaccines are widely utilized in cancer therapy (Palucka and Banchereau, 2013) and infection control (García et al., 2011) as well as in basic research to analyze T-cell response (Roy and Klein, 2012). DCs primed with whole parasites: mimic the natural infection and may increase the success of vaccine approaches in the sense that they are activated directly by pathogens; and stimulate a broader repertoire of $\mathrm{T}$ cells which increases the possibility of a suitable immune response against parasites (Colino and Snapper, 2003).

The current study aimed to evaluate the efficacy of anadjuvant dendritic cell vaccination combined withS. mansoni SEA and SWAP antigens in experimentally infected mice with $S$. mansoni.

\section{Materials and Methods}

\section{Experimental animals}

Mice were obtained from Schistosome Biological Supply Program (SBSP), Theodor Bilharz Research Institute (TBRI), Giza, Egypt and kept under standard housing conditions in the animal house of TBRI. All procedures related to animal experimentation met the International Guiding Principles for Biomedical Research Involving Animals as issued by the International Organizations of Medical Sciences (www.cioms.ch/).

\section{Experimental design}

The study was carried out on 70 laboratory bred CD-1 Swiss albino male mice weighing about $20 \pm 2 \mathrm{gm}$ at the beginning of the experiment. The mice were divided into seven groups each contained 10 mice as follows: Group I control none infected injected by PBS, group II control infected by $\pm 80 S$. mansoni cercariae, group III injected by SEA 
and then infected by $\pm 80 S$. mansoni cercariae, group IV injected by SEA + DCs and then infected by $\pm 80 S$. mansoni cercariae, group $\mathrm{V}$ injected by $S W A P$ and then infected by $\pm 80 S$. mansoni cercariae, group VI injected by SWAP + DCs and then infected by $\pm 80 \mathrm{~S}$. mansoni cercariae and group VII mice were injected with dendritic cells only and then infected by \pm 80 S. mansoni cercariae.

Antigen preparation (Bradford, 1976 and El-Ahwany et al., 2012)

The crude antigens preparations were purified, sterilized by filtration through $0.45 \mu \mathrm{m}$ filters (Nalgene Brand Product, Sybran Corp., Rochester, New York, USA) and the protein content was estimated spectrophotometrically using the Bio-Rad kit (Bio-Rad Laboratories, Hercules, California, USA). Then, it was dissolved in Phosphate Buffered Saline (PBS) for immunization.

\section{Dendritic cells preparation}

Generation of immature DCs (Ma et al., 2017)

Isolation of bone marrow cells from the femurs of three mice. Every femur's bone marrow was cultured in a separate flask $(5 \mathrm{ml})$, six femurs in six flasks. They were cultured in complete media containing $80 \%$ completeRPMI 1640 medium, 20\% fetal bovine serum, $100 \mathrm{U} / \mathrm{ml}$ penicillin, $100 \mathrm{mg} / \mathrm{ml}$ streptomycin supplemented with100 nano gram (ng) $/ \mathrm{ml}$ granulocyte macrophage colony stimulating factor (GM-CSF) and $100 \mathrm{ng} / \mathrm{ml}$ interleukin 4 (IL-4) at $37{ }^{\circ} \mathrm{C}$ and $5 \%$ carbon dioxide $\left(\mathrm{CO}_{2}\right)$ for 3 days. On the $3 \mathrm{rd}$ day, $2 \mathrm{ml}$ of the culture supernatant was carefully removed, and $3 \mathrm{ml}$ of fresh complete culture medium was added to each well and continued to culture for another 2 days at $37{ }^{\circ} \mathrm{C}$ and $5 \% \quad \mathrm{CO}_{2}$. One week later, another dose of GM-CSF and IL-4 after that antigens were added as the follow:300 $\mu$ l SEA or SWAP containing $30 \mu \mathrm{g}$ protein was added to mature DCs as the first dose of vaccine,200 $\mu \mathrm{l}$ SEA orSWAP containing $20 \mu \mathrm{g}$ protein was added to mature DCs as the second dose of vaccine.100 $\mu 1$ SEA orSWAP containing $10 \mu \mathrm{g}$ protein was added to mature DCs as the last dose of vaccine. After one week, the cells were collected, and immature DCs were isolated by using CD11c + MicroBeads (BD system, New Jersey, USA) according to the manufacturer's protocol. These bone marrow DCs were found to be $>95 \% \mathrm{CD} 11 \mathrm{c}+$ as detected by flow cytometry (FACS) (Beckman FC-500MPL, California, USA). After that count of the cells was done. All procedures were performed in the Egyptian Society for Progenitor Cell Research (ESPCR) at 34 el-khshid street, Minal el-roda, Cario, Egypt (Fig. 1).

\section{Vaccine regmin}

The vaccine was given in three doses injected subcutaneously at two weeks' interval according to Etewa et al., (2017): In groups III and $\mathrm{V}$, the first dose is about $300 \mu \mathrm{l}$ of the antigen containing $30 \mu \mathrm{g}$ protein. The second dose is about $200 \mu \mathrm{l}$ of the antigen containing $20 \mu \mathrm{g}$ protein.

The third booster dose is about $100 \mu \mathrm{l}$ of the antigen containing $10 \mu \mathrm{g}$ protein. In groups IV, VI and VII, the dose is $100 \mu 1$ cell suspension at density $10 \% \mathrm{ml}$ that were subjected to $30 \mu \mathrm{g}$ protein in the first dose, 20 $\mu \mathrm{g}$ protein in the second dose and $10 \mu \mathrm{g}$ protein in the last dose of the vaccine( $\mathrm{Li}$ et al., 2010).

Experimental Infection of mice with $S$. mansoni according to Lopes Ida et al.,(2006)

After two weeks of final immunization, mice were infected with $\pm 80 S$. mansoni cercariae (Egyptian strain) by subcutaneous injection. 
Evaluation of the effect of vaccine on murine schistosomasis

After 45 days' post exposure to the cercariae, all mice were sacrificed and subjected to the following parameters:

\section{Parasitological studies}

S. mansoniworm burden,Oogram patternand Ova count per gram tissue (liver and intestine).

Porto-mesenteric worm burden and reduction \% (Duvall and DeWitt, 1967)

Saline Perfusion of $S$. mansoni adult worms from the hepatic vascular compartment was performed. The number of male and female schistosomes as well as the number of couples were counted and recorded for each mouse. The percentage reduction of adult worms after treatment was calculated according to Tendler et al., (1986) using the formula $\mathrm{R}=\mathrm{C}-\mathrm{V} / \mathrm{C} \times$ 100 , where $\mathrm{R}=$ reduction $\%, \mathrm{C}=$ mean number of adult worms from infected nontreated mice, and $\mathrm{V}=$ mean number of adult parasites from treated mice.

\section{Oogram pattern}

This method was performed to detect the percentage of different developmental stages of Schistosoma eggs according to Pellegrino et al., (1962).

Ova count per gram tissue (liver and intestine) (Cheever, 1970; Cheever and Anderson, 1971).

After scarification and perfusion of mice, representative portions of liver and intestine were dried on a filter paper and placed in a glass test tube containing $5 \mathrm{ml}$ of $5 \% \mathrm{KOH}$ solution incubated at $37^{\circ} \mathrm{C}$ for 24 hours until the tissue was completely digested. The samples were then examined and eggs were counted under a light microscope at $\times 40$ magnification

\section{Histopathological study}

Representative specimens of the liver were taken from each sacrificed mouse and sections were prepared and stained with hematoxylin and eosin (H and E) (Harris, 1900).

\section{Evaluation of histopathological study}

The number of granulomas in five successive low power fields $(10 \times 10)$ was counted and recorded. Reduction \% of number of granulomas $=(\mathrm{C}-\mathrm{V} / \mathrm{C}) \times 100$, where $\mathrm{C}$ is the mean number of granulomas in control infected mice and $\mathrm{V}$ is the mean number of granulomas in vaccinated infected mice. Measurement of granuloma diameter $(\mu \mathrm{m})$ : Granulomas were measured by a graduated lens and scale. The mean diameter of each granuloma was calculated by measuring two diameters of the lesion at right angles to each other and the arithmetic mean of the two measurements was then calculated (Mahmoud and Warren, 1974).

For each mouse 40-50 granulomas were measured, the percent reduction in granuloma diameter relative to the $S$. mansoni infected control group was calculated as follows:

Reduction \% of granuloma diameter (ElAhwany et al., 2012)=

Mean granuloma diameter (MGD) of infected control group - MGD of infected vaccinated group x 100

\section{MGD of control infected group}

Immunohistochemical study: through detection of CD4 expression in murine liver tissues. 
Immunohistochemical study for CD4+ cells

All steps were carried out in Pathology Department Menoufiya University according to Hald et al., (2013).

\section{Immune-staining interpretation}

Scoring of the entire section was carried out by using a binocular Olympus light microscope with wide angle (field size of $0.274 \mathrm{~mm}^{2}$, and field diameter of $0.59 \mathrm{~mm}$ ) at x400 magnification.

The presence and intensity of the staining of CD4 immune marker in the cells of liver tissues was evaluated by:

\section{CD4 marker expression}

Positive CD4 staining was identified when the cell membrane alone or together with the cytoplasm showed brown staining, whereas, negativity was considered when no membrane staining was noticed (Hald et al., 2013). The mean percent of $\mathrm{CD} 4$ positive cells: Cells were counted per ten high power fields (h.p.f) and percent was evaluated.

\section{H-Score of CD4 marker as reported by Nie} et al., (2013)

$\mathrm{H}$-score Formula $=$ strong intensity (3) $\mathrm{x}$ percentage + moderate intensity (2) $x$ percentage + mild intensity (1) x percentage + negative staining $(0) \mathrm{x}$ percentage. The final score ranges from 0 to 300 .

\section{Detection of Ig G Level}

It was determined according to the instruction of the ELISA kits (eBioscience). Detection of IgG level was in serum samples of the groups vaccinated before infection, groups (I, III, IV, V, VI \&VII).

\section{Detection of IL-10 and IL-12p40 levels}

They were determined according to the instruction of the ELISA kits (eBioscience). In brief, mouseIL-10 and IL-12p40 were detected by biotinylated monoclonal antibodies, which were evidenced by avidin-conjugated horseradish peroxidase followed by incubation with TMB. Absorbance of the samples and controls was read at 450nm (ELx808 Absorbance MicroplateReader; BioTek).

\section{Statistical analysis}

Data are presented using SPSS version 22.0 (SPSS Inc., Chicago, Illinois, USA) on an IBMcompatible computer. Variable parameters were presented as the mean $\pm \mathrm{SD}$. Group comparisons were assessed by ANOVA test for statistically significant differences, defined as a $p$ value $\leq 0.05$ using GraphPad Prism software (Version 7.02) ( $\mathrm{p}$ value $\leq 0.05 ; \mathrm{p}$ value $\leq 0.001 ; \mathrm{p}$ value $\leq$ 0.0001).The Kruskal-Wallis test was applied to study the difference between the groups having nonparametric variables (worm burden).

\section{Results and Discussion}

The development of a protective vaccine against schistosomiasis still remains potentially the most effective mean for controlling the disease (Merrifield et al., 2016). The current Schistosoma vaccine candidates prove not to be the most effective, so it is important to identify new antigens and to explore alternative vaccination strategies, including new adjuvants to improve vaccine efficacy (McManus and Loukas, 2008).

\section{Parasitological parameters}

The highest reduction of total S. mansoni worm burden was $77.8 \%, 70.2 \%$, in group IV and group VI respectively and all tested 
groups showed significant reductionin comparison to control group (P6: 0.001) (table 1). Regarding schistosomal oogram pattern, the least percentage of immature eggs in oogram pattern were $21.1 \pm 3.41$ in group IV (SEA+DCs) followed by $25.9 \pm 3.72$ in group VI (SWAP+DCs) compared to $52.8 \pm 1.98$ for control infected group II with the presence of statistically significant difference. There was a significant reduction in the percentage of mature ova where the least percentage was $14.1 \pm 2.42$ in group IV (SEA+ DCs) followed by $17 \pm 1.63$ in group VI (SWAP+ DCs) versus $42.1 \pm 1.66$ for control infected group II with a highly statistically significant difference $(p<0.001)$. There was highly significant difference to all groups in comparison to control group where the highest percentage of dead eggs were achieved in group IV (SEA+DCs) 64.8 \pm 4.31 followed by group VI

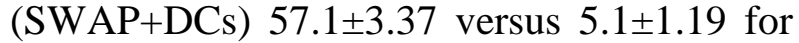
control infected one and there was highly significant difference between group III (SEA) and group IV (SEA + DCs), group V (SWAP) and group VI (SWAP + DCs) as $\mathrm{P}$ values were, P6: 0.001 and P13:0.001, respectively (table 2).Egg viability is an important parameter for the evaluation of efficacy of vaccines. Accordingly, in the present study, there were changes in the oogram pattern, including a significant reduction in the percentage of immature and mature ova and the highest percentage of dead eggs was in DCs combined groups. These results are in agreement with results obtained by Ismail, (2005) and those by Etewa et al., (2014). The reasonable explanation for these results may be the presence of predictable antibodies $\operatorname{IgM}$, $\mathrm{IgG}$, and $\operatorname{IgA}$ classes in response to worm antigens as reported by Dunne et al., (1993). Furthermore, a decrease in the intestinal egg burden might reflect a consequent reduction in disease transmission by reducing the passage of Schistosoma eggs into the intestinal lumen from the mesenteric veins (Ranasinghe et al., 2018).
Also, combined groups showed the least number of ova/gram tissue of the liver; $1345 \pm 738.4$ with reduction percent $87 \%$ in group IV (SEA+ DCs) followed by $1560 \pm 337.3$ with reduction percent $84.9 \%$ in group VI (SWAP+ DCs) versus 10355 \pm 3020.7 for control infected group II. The least number of ova/gram tissue of the intestine was also in the same combined groups, $2103 \pm 617.8$ with reduction percent $82.7 \%$ in group IV (SEA+ DCs) followed by $2410 \pm 483.6$ with reduction percent $80.3 \%$ in group VI (SWAP+ DCs) versus $12215 \pm 3539.6$ for control infected group II (Table 3). According to WHO benchmark for progression of a Schistosoma vaccine antigen into clinical assessment, a molecule that can consistently induce $40 \%$ protection or better is considered as an optimal anti-schistosome vaccine candidate, and a significant reduction in adult worm numbers represents a high standard when considering an effective anti-schistosome vaccine target (McManus and Loukas, 2008).

In the present study there were significant reductions in all assessed parasitological parameters, the adults' worm burden, hepatic and intestinal egg load with increased percentage of dead eggs in combined vaccinated groups with DCs. This could be due to enhancement of immune response. As, DCs are critical in the activation of $\mathrm{T}$ cells, providing antigen presentation, costimulatory signals and inflammatory cytokine stimulation to direct an effector $\mathrm{T}$ cell response (Constantino et al., 2017). These results are supported by a number of previous studies on other antischistosomal vaccines (Abdameleket al., 2014, Etewa et al., 2014 and Selim et al., 2016). In addition, Li et al., (2010) reported that dendritic cells pulsed with Glutathion Stransferase in combination with $\mathrm{CpG}$ oligodeoxynucleotide induce significant immunoprotection against the infection of $S$. japonicum. 


\section{Histopathological results}

Haematoxylin and eosin sections of liver tissue showed that the mean number of hepatic granulomas in combined groups was significantly lower than other groups. Hence, the reduction percentages of hepatic granuloma number reached $80.7 \%$ in group IV (SEA+ DCs) and $68.1 \%$ in group VI (SWAP+ DCs) with significant difference between combined groups (P11: 0.011) (Table 4\&Fig. 2). Also, size of granulomas decreased in combined groups with reduction percentages of hepatic granuloma diameter reached $54.2 \%$ for group IV (SEA+ DCs) and
$45.6 \%$ for group VI (SWAP+ DCs)(Table 4\&Fig. 3). These results indicated the increase in Th1 response by its specific cytokines which was reflected positively on the number and size of hepatic Schistosoma granulomas leading to decrease in number and size of them (Etewa et al., 2017). These are in harmony with those of Ismail, (2005), Oliveira et al., (2012) and Etewa et al., (2017). These observations can be explained by the statement of Chitsulo et al., (2004), who pointed out that a vaccine that induces even a partial reduction in worm burdens could reduce pathology and limit parasite transmission.

Table.1 Comparison between the studied groups regarding the mean total worm load $(\mathrm{N}=60)$

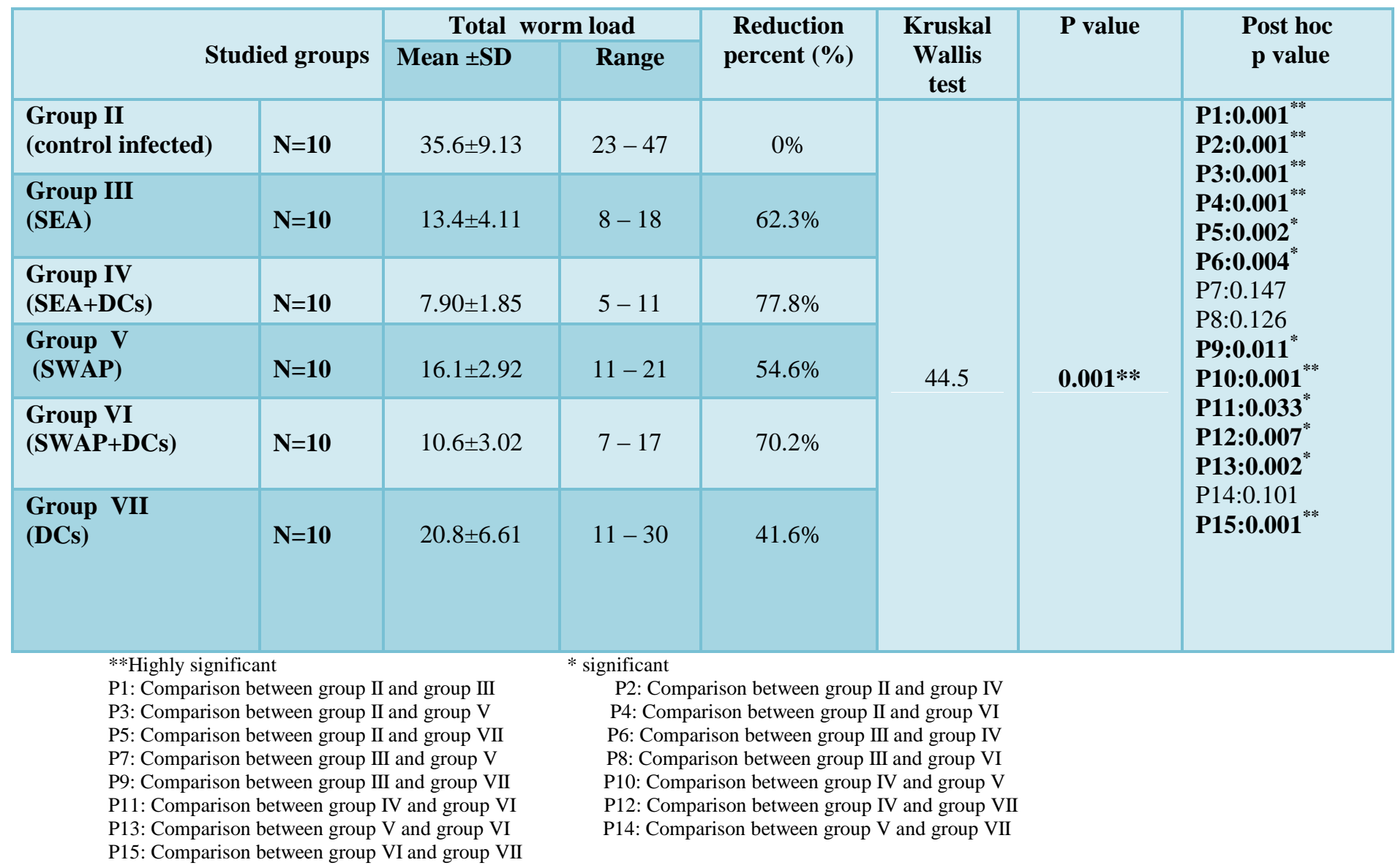


Table. 2 Comparison between the studied groups regarding the mean number of $S$. mansoni eggs in oogram pattern $(\mathrm{N}=60)$

\begin{tabular}{|c|c|c|c|c|c|c|}
\hline \multirow{2}{*}{\multicolumn{2}{|c|}{ Studied groups }} & \multicolumn{2}{|c|}{ Number of immature egg } & \multirow[t]{2}{*}{ ANOVA } & \multirow[t]{2}{*}{ P value } & \multirow{2}{*}{$\begin{array}{l}\text { Post hoc } \\
\text { p value }\end{array}$} \\
\hline & & Mean \pm SD & \multirow{2}{*}{$\begin{array}{l}\text { Range } \\
50-55\end{array}$} & & & \\
\hline $\begin{array}{l}\text { Group II } \\
\text { (control infected) }\end{array}$ & $\mathrm{N}=10$ & $52.8 \pm 1.98$ & & \multirow{6}{*}{52.3} & \multirow{6}{*}{$0.001 * *$} & \multirow{6}{*}{$\begin{array}{l}\text { P1:0.001 } \\
\text { P2:0.001 } \\
\text { P3:0.001 } \\
\text { P** } \\
\text { P4:0.001 } \\
\text { P5:0.001 } \\
\text { P6:0.001 } \\
\text { P** } \\
\text { P7:0.001 } \\
\text { P8:0.149 } \\
\text { P9:0.001 } \\
\text { P10:0.001 } \\
\text { P11:0.011 }^{* *} \\
\text { P12:0.001 }^{* *} \\
\text { P13:0.001 }^{* *} \\
\text { P14:0.003 }^{* *} \\
\text { P15:0.001 }\end{array}$} \\
\hline $\begin{array}{l}\text { Group III } \\
\text { (SEA) }\end{array}$ & $\mathrm{N}=10$ & $28.3 \pm 3.94$ & $22-34$ & & & \\
\hline Group IV (SEA+DCs) & $\mathbf{N}=10$ & $21.1 \pm 3.41$ & $16-27$ & & & \\
\hline $\begin{array}{l}\text { Group V } \\
\text { (SWAP) }\end{array}$ & $\mathbf{N}=\mathbf{1 0}$ & $34.0 \pm 1.56$ & $32-37$ & & & \\
\hline Group VI (SWAP+DCs) & $\mathrm{N}=10$ & $25.9 \pm 3.72$ & $20-33$ & & & \\
\hline $\begin{array}{l}\text { Group VII } \\
\text { (DCs) }\end{array}$ & $\mathbf{N}=10$ & \multirow[t]{2}{*}{$38.6 \pm 2.98$} & $34-43$ & & & \\
\hline \multicolumn{6}{|c|}{ Number of mature egg } & \\
\hline $\begin{array}{l}\text { Group II } \\
\text { (control infected) }\end{array}$ & $\mathbf{N}=\mathbf{1 0}$ & $42.1 \pm 1.66$ & $40-45$ & \multirow{6}{*}{54.2} & \multirow{6}{*}{$0.001 * *$} & \multirow{6}{*}{$\begin{array}{l}\text { P1:0.001** } \\
\text { P2:0.001** } \\
\text { P3:0.001 } \\
\text { P4:0.001** } \\
\text { P5:0.001** } \\
\text { P6:0.001 } \\
\text { P7:0.001 } \\
\text { P8:0.023* } \\
\text { P9:0.001 } \\
\text { P10:0.001 } \\
\text { P11:0.004 } \\
\text { P12:0.001 } \\
\text { P13:0.001 } \\
\text { P14:0.001 } \\
\text { P15:0.001 } \\
\text { ** }\end{array}$} \\
\hline $\begin{array}{l}\text { Group III } \\
\text { (SEA) }\end{array}$ & $\mathrm{N}=10$ & $19.2 \pm 2.34$ & $15-22$ & & & \\
\hline Group IV (SEA+DCs) & $\mathrm{N}=\mathbf{1 0}$ & $14.1 \pm 2.42$ & $12-20$ & & & \\
\hline $\begin{array}{l}\text { Group V } \\
\text { (SWAP) }\end{array}$ & $\mathbf{N}=10$ & $24.8 \pm 1.87$ & $21-28$ & & & \\
\hline Group VI (SWAP+DCs) & $\mathrm{N}=10$ & $17.0 \pm 1.63$ & $15-20$ & & & \\
\hline $\begin{array}{l}\text { Group VII } \\
\text { (DCs) }\end{array}$ & $N=10$ & $29.2 \pm 1.47$ & $26-31$ & & & \\
\hline \multicolumn{7}{|c|}{ Number of dead egg } \\
\hline $\begin{array}{l}\text { Group II } \\
\text { (control infected) }\end{array}$ & $\mathrm{N}=10$ & $5.10 \pm 1.19$ & $3-7$ & \multirow{6}{*}{55.4} & \multirow{6}{*}{$0.001 * *$} & $\begin{array}{l}\text { P1:0.001 } \\
\text { P2:0.001*** }\end{array}$ \\
\hline $\begin{array}{l}\text { Group III } \\
\text { (SEA) }\end{array}$ & $\mathrm{N}=\mathbf{1 0}$ & $52.5 \pm 3.95$ & $48-60$ & & & $\begin{array}{l}\text { P3:0.001 } \\
\text { P4:0.001*** } \\
\text { P5:0.001** }\end{array}$ \\
\hline Group IV (SEA+DCs) & $\mathrm{N}=10$ & $64.8 \pm 4.31$ & $55-69$ & & & $\begin{array}{l}\text { P6:0.001** } \\
\text { P7:0.001** }\end{array}$ \\
\hline $\begin{array}{l}\text { Group V } \\
\text { (SWAP) }\end{array}$ & $\mathbf{N}=10$ & $41.2 \pm 1.54$ & $39-44$ & & & $\begin{array}{l}\text { P8:0.017 } \\
\text { P9:0.001 } \\
\text { P10:0.001 }\end{array}$ \\
\hline Group VI (SWAP+DCs) & $\mathrm{N}=\mathbf{1 0}$ & $57.1 \pm 3.37$ & $52-64$ & & & $\begin{array}{l}\text { P11:0.002* } \\
\text { P12:0.001** }\end{array}$ \\
\hline $\begin{array}{l}\text { Group VII } \\
\text { (DCs) }\end{array}$ & $\mathbf{N}=10$ & $32.2 \pm 3.35$ & $27-36$ & & & $\begin{array}{l}\text { P13:0.001** } \\
\text { P14:0.001** } \\
\text { P15:0.001** }\end{array}$ \\
\hline $\begin{array}{l}\text { **Highly significant } \\
\text { P1: Comparison betwe } \\
\text { P3: Comparison betwe } \\
\text { P5: Comparison betwe } \\
\text { P7: Comparison betwe } \\
\text { P9: Comparison betwe } \\
\text { P11: Comparison betw } \\
\text { P13: Comparison betw } \\
\text { P15: Comparison betw }\end{array}$ & $\begin{array}{l}\text { oup II and gro } \\
\text { oup II and gro } \\
\text { oup II and gro } \\
\text { oup III and gro } \\
\text { oup III and grc } \\
\text { roup IV and g } \\
\text { roup V and gr } \\
\text { roup VI and g }\end{array}$ & $\begin{array}{l}\text { p III } \\
p \text { V } \\
\text { p VII } \\
\text { up V } \\
\text { up VII } \\
\text { oup VI } \\
\text { up VI } \\
\text { oup VII }\end{array}$ & $\begin{array}{l}\text { arison bet } \\
\text { arison bet } \\
\text { arison bet } \\
\text { arison bet } \\
\text { arison be } \\
\text { parison be } \\
\text { arison be }\end{array}$ & $\begin{array}{l}\text { oup II and } \\
\text { roup II and } \\
\text { roup III and } \\
\text { roup III and } \\
\text { group IV an } \\
\text { group IV an } \\
\text { group V an }\end{array}$ & $\begin{array}{l}\text { IV } \\
\text { VI } \\
\text { IV } \\
\text { VI } \\
\text { p V } \\
\text { p VII } \\
\text { VII }\end{array}$ & \\
\hline
\end{tabular}


Table.3 Comparison between the studied groups regarding the mean number of ova / gram tissue of liver and intestine $(\mathrm{N}=60)$

\begin{tabular}{|c|c|c|c|c|c|c|c|}
\hline \multirow{2}{*}{\multicolumn{2}{|c|}{ Studied groups }} & \multicolumn{2}{|c|}{ Number of ova / gram tissue of liver } & \multirow{2}{*}{$\begin{array}{c}\text { Reduction } \\
\text { percent }(\%)\end{array}$} & \multirow[b]{2}{*}{$\mathbf{K}$} & \multirow[t]{2}{*}{$P$ value } & \multirow{2}{*}{$\begin{array}{c}\text { Post hoc } \\
\text { p value }\end{array}$} \\
\hline & & Mean \pm SD & Range & & & & \\
\hline $\begin{array}{l}\text { Group II } \\
\text { (control infected) }\end{array}$ & $\mathbf{N}=\mathbf{1 0}$ & $10355 \pm 3020.7$ & $7750-15500$ & $0 \%$ & \multirow{7}{*}{44.4} & \multirow{7}{*}{$0.001 * *$} & \multirow{6}{*}{$\begin{array}{l}\text { P1:0.001 } \\
\text { P2:0.001 } \\
\text { P3:0.001 } \\
\text { *** } \\
\text { P4:0.001 } \\
\text { P5:0.001 } \\
\text { ** } \\
\text { P6:0.121 } \\
\text { P7:0.427 } \\
\text { P8:0.173 } \\
\text { P9:0.001 } \\
\text { P10:0.041 } \\
\text { P1 } \\
\text { P1:0.273 } \\
\text { P12:0.001 } \\
\text { P13:0.019 } \\
\text { P14:0.001 } \\
\text { ** } \\
\text { P15:0.001 }\end{array}$} \\
\hline $\begin{array}{l}\text { Group III } \\
\text { (SEA) }\end{array}$ & $\mathrm{N}=10$ & $1840.0 \pm 450.1$ & $1200-2500$ & $82.2 \%$ & & & \\
\hline $\begin{array}{l}\text { Group IV } \\
\text { (SEA+ DCs) }\end{array}$ & $\mathrm{N}=\mathbf{1 0}$ & $1345.0 \pm 738.4$ & $550-2450$ & $87.0 \%$ & & & \\
\hline $\begin{array}{l}\text { Group V } \\
\text { (SWAP) }\end{array}$ & $\mathbf{N}=\mathbf{1 0}$ & $2050.0 \pm 392.2$ & $1600-2800$ & $80.2 \%$ & & & \\
\hline Group VI (SWAP+DCs) & $\mathrm{N}=\mathbf{1 0}$ & $1560.0 \pm 337.3$ & $1100-2050$ & $84.9 \%$ & & & \\
\hline $\begin{array}{l}\text { Group VII } \\
\text { (DCs) }\end{array}$ & $\mathrm{N}=\mathbf{1 0}$ & $4030.0 \pm 1119.5$ & $2950-6800$ & $61.0 \%$ & & & \\
\hline \multicolumn{6}{|c|}{ Number of ova / gram tissue of intestine } & & \\
\hline $\begin{array}{l}\text { Group II } \\
\text { (control infected) }\end{array}$ & $\mathbf{N}=\mathbf{1 0}$ & $12215.0 \pm 3539.6$ & $8200-17700$ & $0 \%$ & \multirow{6}{*}{71.2} & \multirow{6}{*}{$0.001 * *$} & \multirow{6}{*}{$\begin{array}{l}\text { P1:0.001 } \\
\text { P2:0.001 } \\
\text { P3:0.001 } \\
\text { *** } \\
\text { P4:0.001 } \\
\text { P5:0.001 } \\
\text { *** } \\
\text { P6:0.198 } \\
\text { P7:0.660 } \\
\text { P8:0.558 } \\
\text { P9:0.001 } \\
\text { P10:0.141 } \\
\text { P11:0.648 } \\
\text { P12:0.001 } \\
\text { P13:0.306 } \\
\text { P14:0.001 } \\
\text { P15:0.001 } \\
\text { *** }\end{array}$} \\
\hline $\begin{array}{l}\text { Group III } \\
\text { (SEA) }\end{array}$ & $\mathrm{N}=10$ & $2804.5 \pm 658.5$ & $1900-3850$ & $77.0 \%$ & & & \\
\hline $\begin{array}{l}\text { Group IV } \\
\text { (SEA+ DCs) }\end{array}$ & $\mathbf{N}=\mathbf{1 0}$ & $2103.0 \pm 617.8$ & $1100-2900$ & $82.7 \%$ & & & \\
\hline $\begin{array}{r}\text { Group V } \\
\text { (SWAP) }\end{array}$ & $\mathrm{N}=\mathbf{1 0}$ & $3100.0 \pm 483.6$ & $2250-3950$ & $74.6 \%$ & & & \\
\hline Group VI (SWAP+DCs) & $\mathrm{N}=\mathbf{1 0}$ & $2410.0 \pm 483.6$ & $1750-2950$ & $80.3 \%$ & & & \\
\hline $\begin{array}{l}\text { Group VII } \\
\text { (DCs) }\end{array}$ & $\mathrm{N}=10$ & $5985.0 \pm 1377.6$ & $4300-8050$ & $51.0 \%$ & & & \\
\hline
\end{tabular}

**Highly significant

P1: Comparison between group II and group III P3: Comparison between group II and group V P5: Comparison between group II and group VII P7: Comparison between group III and group V P9: Comparison between group III and group VII P11: Comparison between group IV and group VI P13: Comparison between group V and group VI P15: Comparison between group VI and group VII
P2: Comparison between group II and group IV P4: Comparison between group II and group VI P6: Comparison between group III and group IV P8: Comparison between group III and group VI P10: Comparison between group IV and group V P12: Comparison between group IV and group VII P14: Comparison between group V and group VII 
Table.4 Comparison between the studied groups regarding the mean number and diameter of hepatic granuloma $(\mathrm{N}=60)$

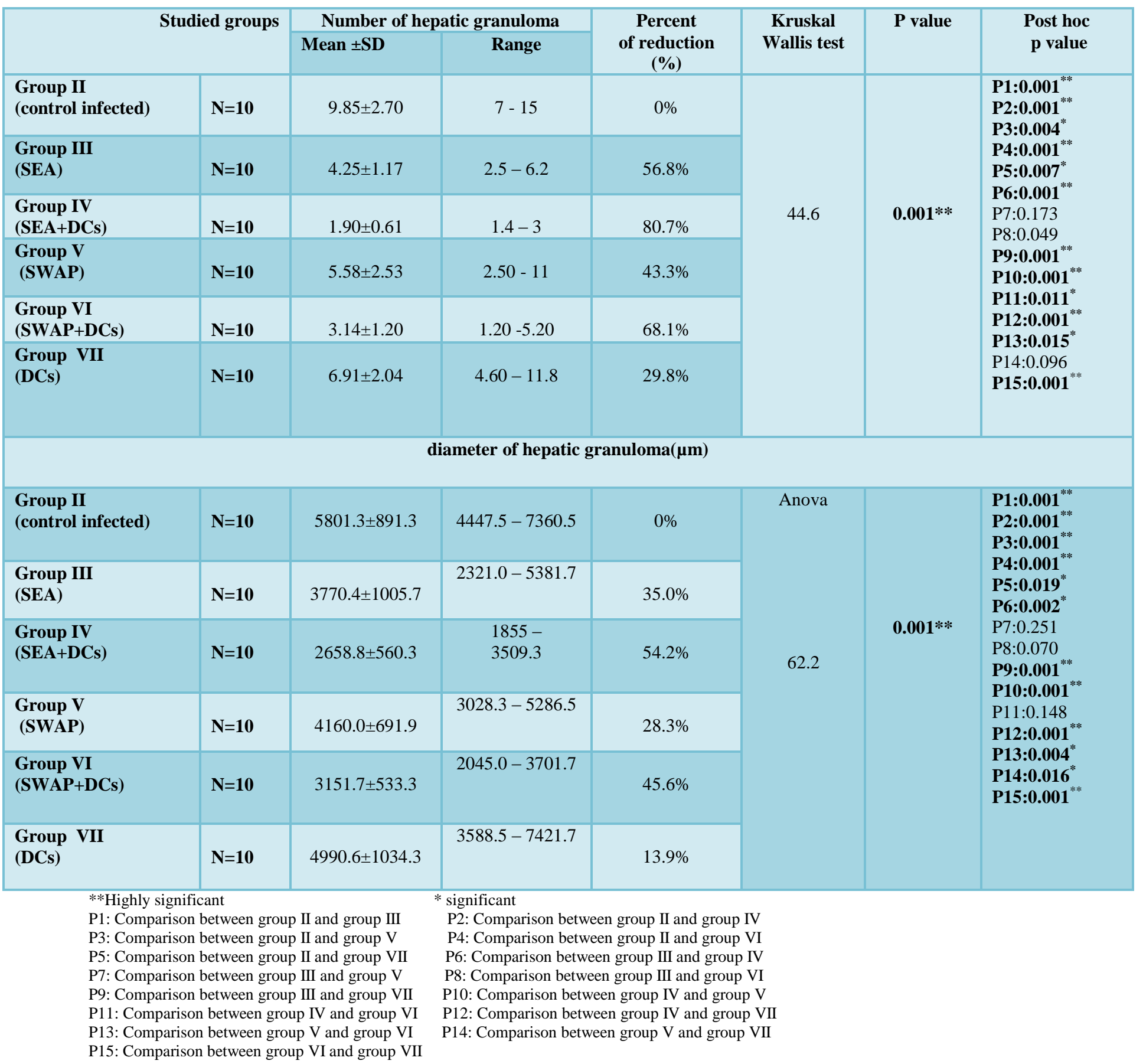


Table.5 Comparison between the studied groups regarding the mean percent of CD4 positive cells in liver $(\mathrm{N}=70)$

\begin{tabular}{|c|c|c|c|c|c|c|}
\hline \multirow{2}{*}{\multicolumn{2}{|c|}{ Studied groups }} & \multicolumn{2}{|c|}{$\begin{array}{l}\text { Percent of CD4 positive cells in } \\
\text { liver }\end{array}$} & \multirow[t]{2}{*}{ ANOVA } & \multirow[t]{2}{*}{$P$ value } & \multirow[t]{2}{*}{$\begin{array}{r}\text { Post hoc } \\
\text { p value }\end{array}$} \\
\hline & & Mean \pm SD & Range & & & \\
\hline $\begin{array}{l}\text { Group II } \\
\text { (control infected) }\end{array}$ & $\mathrm{N}=\mathbf{1 0}$ & $25.0 \pm 4.71$ & $20-35$ & \multirow{6}{*}{50.2} & \multirow{6}{*}{$0.001 * *$} & \multirow{6}{*}{$\begin{array}{l}\text { P1:0.001 } \\
\text { P2:0.001 } \\
\text { P3:0.001 } \\
\text { P4: } \\
\text { P4:001 } \\
\text { P5:0.001 } \\
\text { P6:0.021 } \\
\text { P7: } \\
\text { P7: } 0.256 \\
\text { P8:0.112 } \\
\text { P9:0.001 } \\
\text { P10:0.003 }^{* *} \\
\text { P11:0.344 } \\
\text { P12:0.001 } \\
\text { P13:0.006 } \\
\text { P14:0.001 } \\
\text { P** } \\
\text { P15:0.001 }\end{array}$} \\
\hline $\begin{array}{l}\text { Group III } \\
\text { (SEA) }\end{array}$ & $\mathrm{N}=10$ & $40.0 \pm 4.71$ & $35-50$ & & & \\
\hline Group IV (SEA+DCs) & $\mathrm{N}=\mathbf{1 0}$ & $60.0 \pm 9.12$ & $45-75$ & & & \\
\hline $\begin{array}{l}\text { Group V } \\
\text { (SWAP) }\end{array}$ & $\mathbf{N}=\mathbf{1 0}$ & $35.0 \pm 4.71$ & $30-45$ & & & \\
\hline Group VI (SWAP+DCs) & $\mathrm{N}=\mathbf{1 0}$ & $50.0 \pm 4.71$ & $45-60$ & & & \\
\hline $\begin{array}{l}\text { Group VII } \\
\text { (DCs) }\end{array}$ & $\mathrm{N}=10$ & $30.0 \pm 4.71$ & $25-40$ & & & \\
\hline
\end{tabular}

**Highly significant

P1: Comparison between group II and group III P3: Comparison between group II and group V P5: Comparison between group II and group VII P7: Comparison between group III and group V P9: Comparison between group III and group VII P11: Comparison between group IV and group VI P13: Comparison between group V and group VI P15: Comparison between group VI and group VII
* significant

P2: Comparison between group II and group IV P4: Comparison between group II and group VI P6: Comparison between group III and group IV P8: Comparison between group III and group VI P10: Comparison between group IV and group V P12: Comparison between group IV and group VII P14: Comparison between group V and group VII

Table.6 Comparison between the studied groups regarding the mean H score of CD4 in liver $(\mathrm{N}=60)$

\begin{tabular}{|c|c|c|c|c|c|c|}
\hline \multirow{2}{*}{\multicolumn{2}{|c|}{ Studied groups }} & \multicolumn{2}{|c|}{ H score of CD4 in liver } & \multirow[t]{2}{*}{ ANOVA } & \multirow[t]{2}{*}{ P value } & \multirow{2}{*}{$\begin{array}{r}\text { Post hoc } \\
\text { p value }\end{array}$} \\
\hline & & Mean \pm SD & Range & & & \\
\hline $\begin{array}{l}\text { Group II } \\
\text { (control infected) }\end{array}$ & $\mathrm{N}=\mathbf{1 0}$ & $55.0 \pm 8.81$ & $45-70$ & \multirow{6}{*}{57.4} & \multirow{6}{*}{$0.001 * *$} & \multirow{6}{*}{ 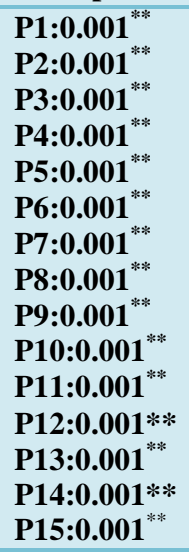 } \\
\hline $\begin{array}{l}\text { Group III } \\
\text { (SEA) }\end{array}$ & $\mathbf{N}=\mathbf{1 0}$ & $110.0 \pm 10.0$ & $100-125$ & & & \\
\hline $\begin{array}{l}\text { Group IV } \\
(\text { SEA+DCs) }\end{array}$ & $\mathbf{N}=\mathbf{1 0}$ & $170.0 \pm 9.12$ & $155-185$ & & & \\
\hline $\begin{array}{l}\text { Group V } \\
\text { (SWAP) }\end{array}$ & $\mathrm{N}=10$ & $95.0 \pm 4.71$ & $90-105$ & & & \\
\hline Group VI (SWAP+DCs) & $\mathbf{N}=10$ & $140.0 \pm 8.81$ & $130-155$ & & & \\
\hline $\begin{array}{l}\text { Group VII } \\
\text { (DCs) }\end{array}$ & $\mathrm{N}=\mathbf{1 0}$ & $80.0 \pm 4.71$ & $75-90$ & & & \\
\hline
\end{tabular}

**Highly significant

P1: Comparison between group II and group III P3: Comparison between group II and group V P5: Comparison between group II and group VII P7: Comparison between group III and group V P9: Comparison between group III and group VII P11: Comparison between group IV and group VI P13: Comparison between group V and group VI P15: Comparison between group VI and group VII
P2: Comparison between group II and group IV P4: Comparison between group II and group VI P6: Comparison between group III and group IV P8: Comparison between group III and group VI P10: Comparison between group IV and group V P12: Comparison between group IV and group VII P14: Comparison between group V and group VII 
Fig.1(a) Dendritic cells in culture during maturation process (red arrows). (b): Mature unstained dendritic cells in culture (red arrows)
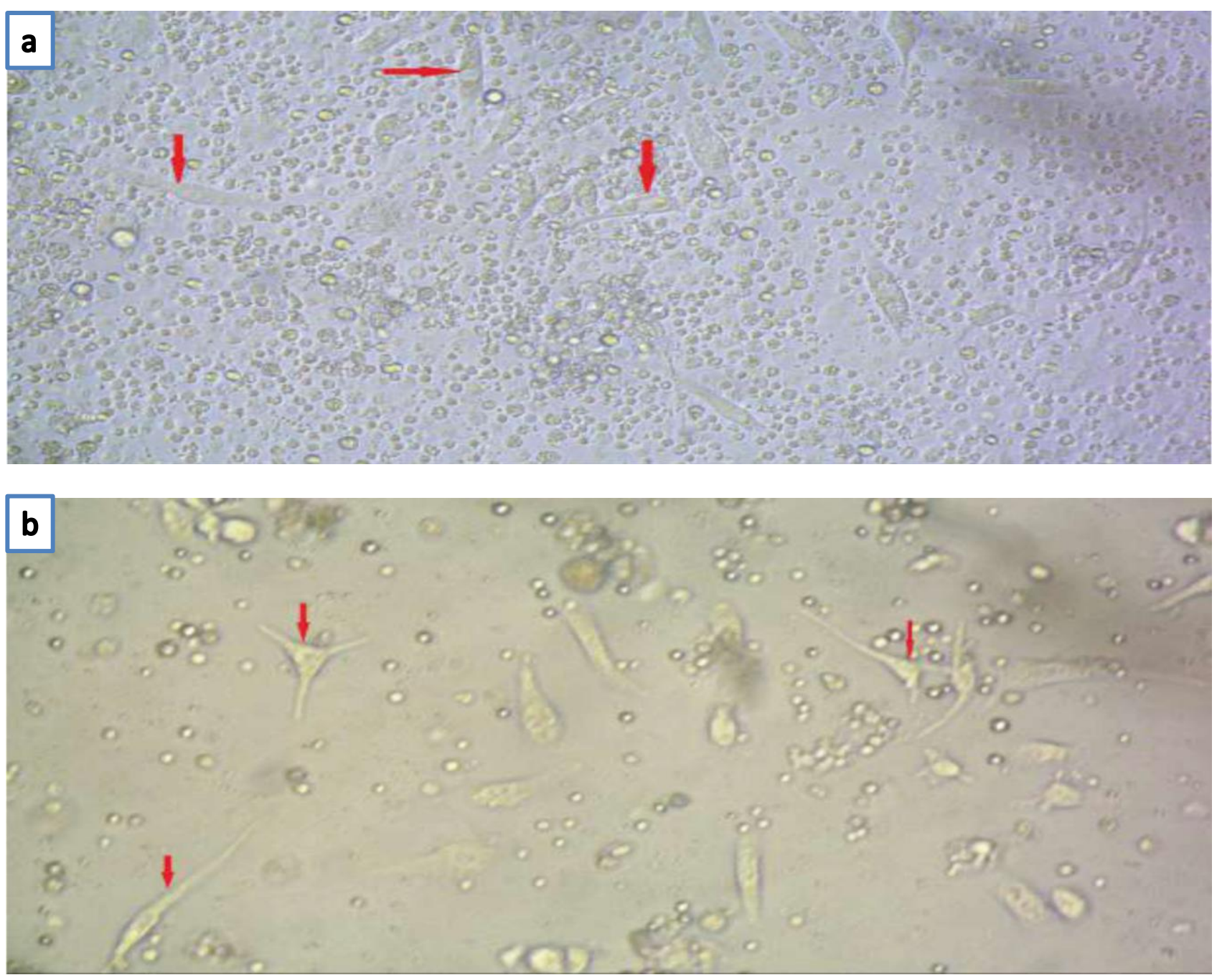
Fig.2(a) A control infected mouse liver tissue revealed nine granulomas as a mean number (x 40). (b): Liver section of a mouse vaccinated with SEA (group III) revealed five granulomas as a mean number (x 40). (c): Liver section of a mouse vaccinated with SEA and dendritic cells (group IV) revealed two granulomas as a mean number (x 40). (d): Liver section of a mouse vaccinated with SWAP (group V) revealed six granulomas as a mean number (x 40). Liver section of a mouse vaccinated with SWAP and dendritic cells (group VI) revealed four granulomas as a mean number (x 40). Liver section of a mouse vaccinated with dendritic cells (group VII) revealed seven granulomas as a mean number ( $x$ 40)
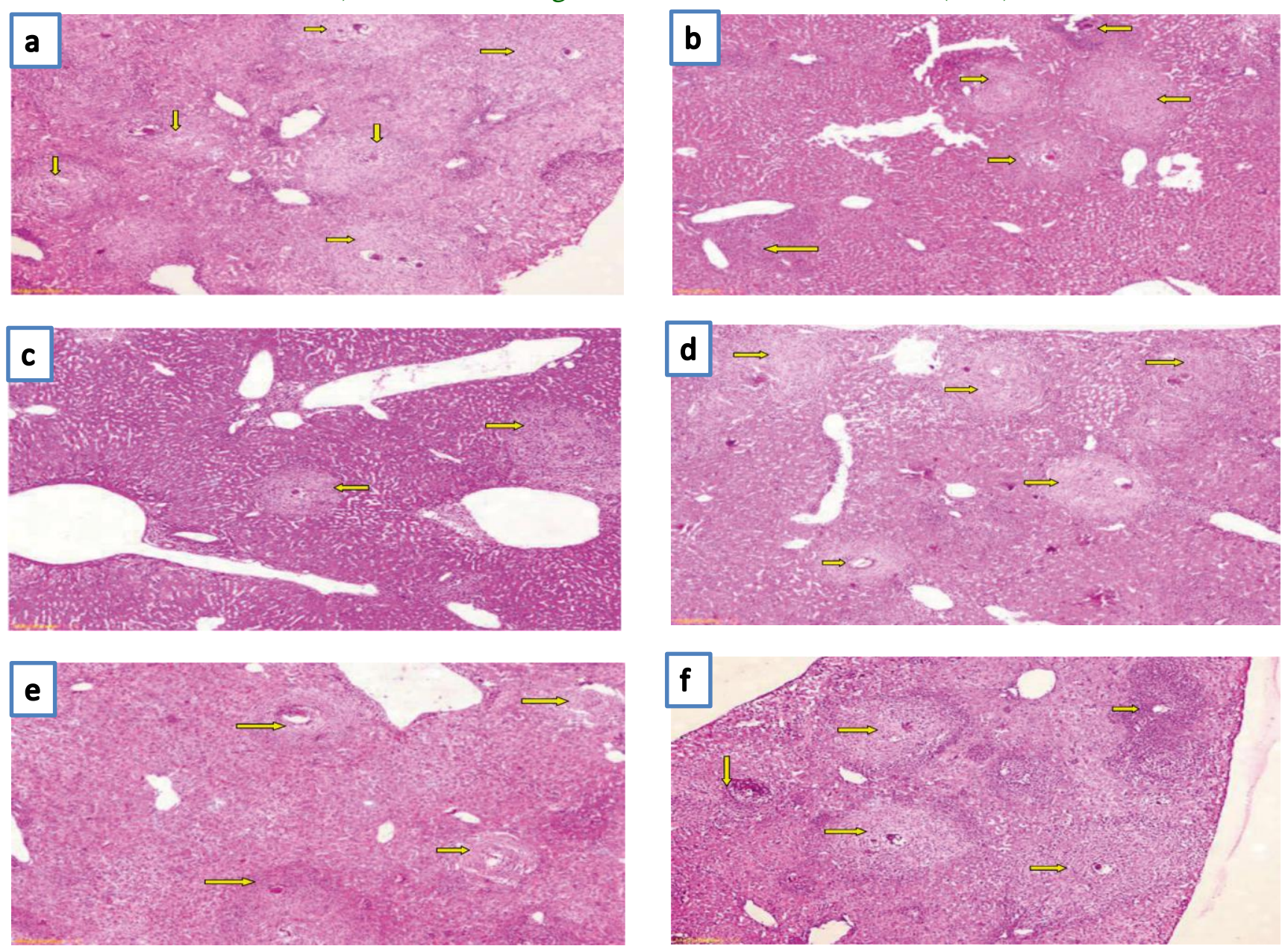
Fig.3(a) Liver section of an infected control mouse showing large size granuloma with massive cellular infiltrate surrounding multiple bilharzial ova (x100). (b): Liver section of an infected mouse vaccinated with SEA revealed the median size of granulomas (X 100). (c): Liver section of an infected mouse vaccinated with SEA and dendritic cells showing small size granuloma with massive cellular infiltrate surrounding multiple bilharzial ova (x100). (d): Liver section of an infected mouse vaccinated with SWAP revealed the median size of granulomas (X 100). (e): Liver section of an infected mouse vaccinated with SWAP and dendritic cells revealed the median size of granulomas (X 100). Liver section of an infected mouse vaccinated with dendritic cells revealed the median size of granulomas (X 100)
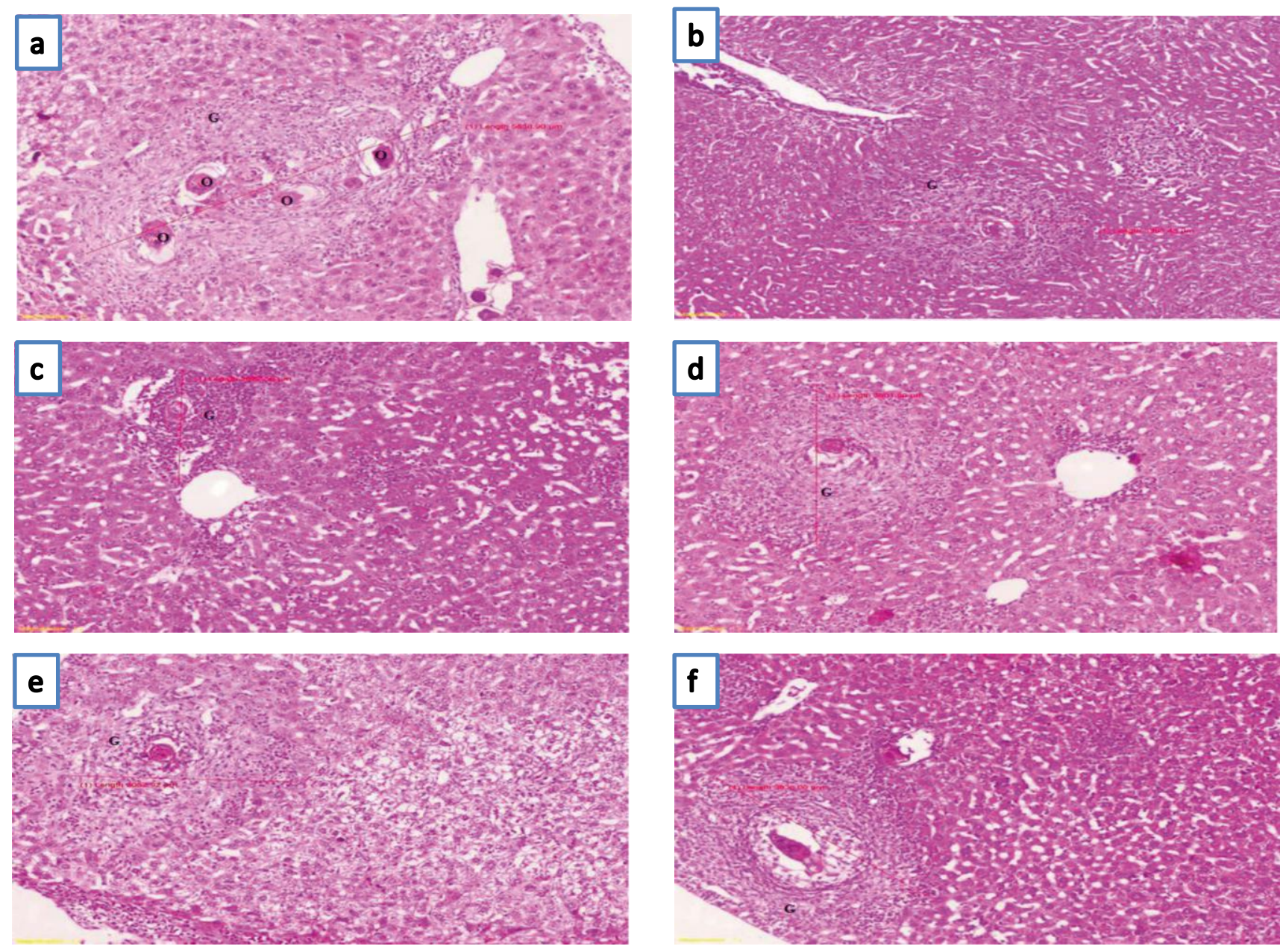
Fig.4(a) Liver section of control infected mouse showing positive CD4 membranous expression in few lymphocytes (x 400). (b): Liver section of infected mouse vaccinated with SEA showing positive CD4 membranous expression in $35 \%$ of lymphocytes (x 400). (c): Liver section of infected mouse vaccinated with SEA and dendritic cells showing diffuse strong positive CD4 membranous expression in majority of lymphocytes (x 400). (d): Liver section of infected mouse vaccinated with SWAP showing positive CD4 membranous expression in $30 \%$ of lymphocytes (x 400). (e): Liver section of infected mouse vaccinated with SWAP and dendritic cells showing positive CD4 membranous expression in $40 \%$ of lymphocytes (x 400). Liver section of infected mouse vaccinated with dendritic cells showing positive CD4 membranous expression in $20 \%$ of lymphocytes (x 400)
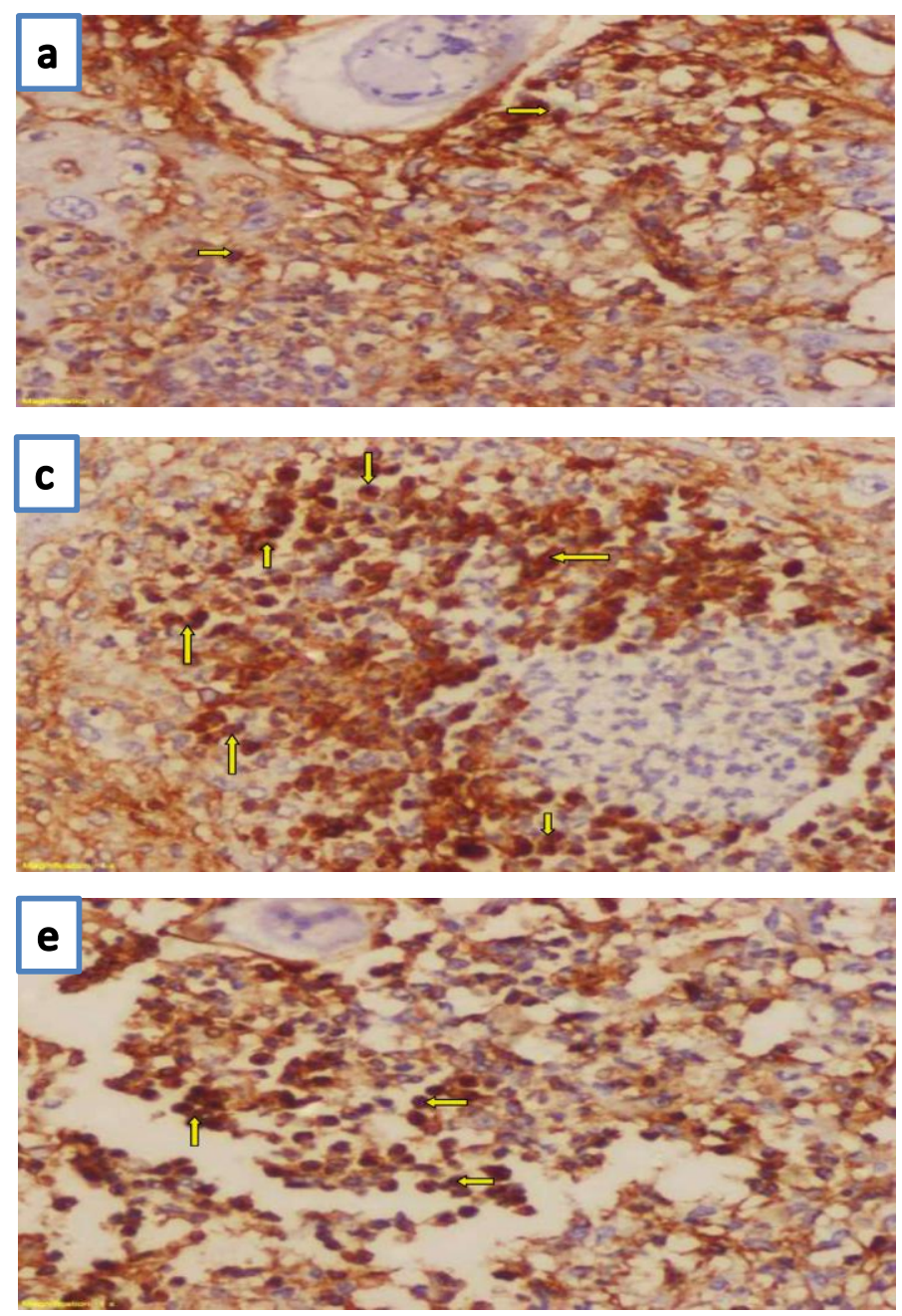
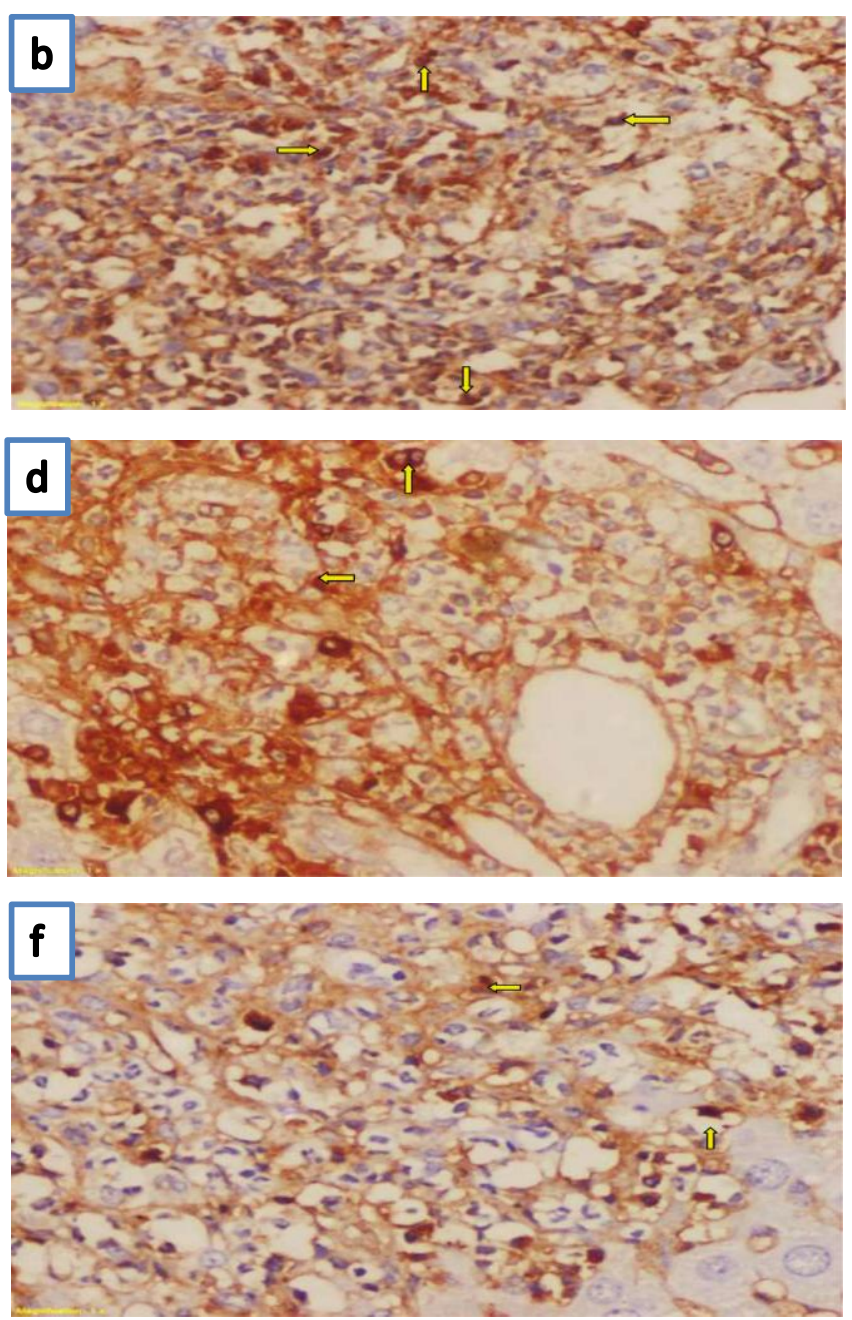
Graph.1 Mean serum IgG level (mg/dl) among the studied groups

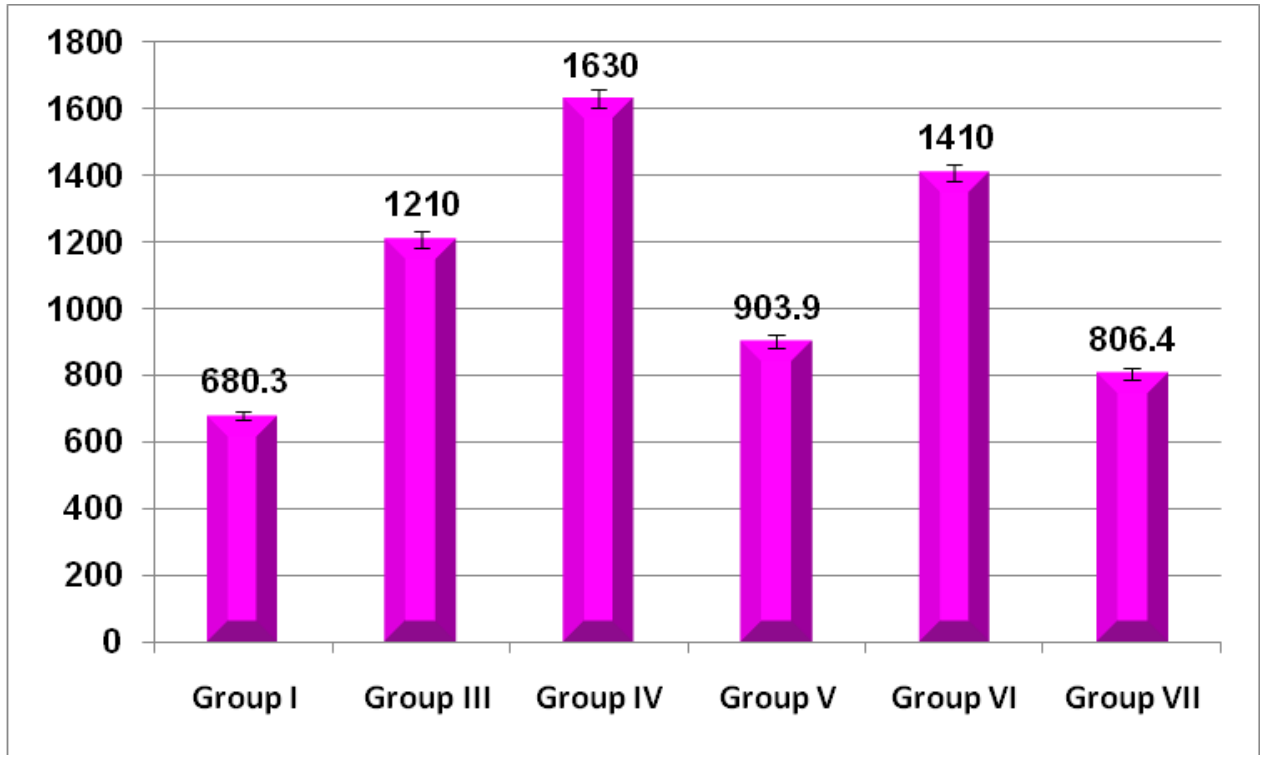

Graph.2 Mean serum IL 10 level (pg /dl) among the studied groups

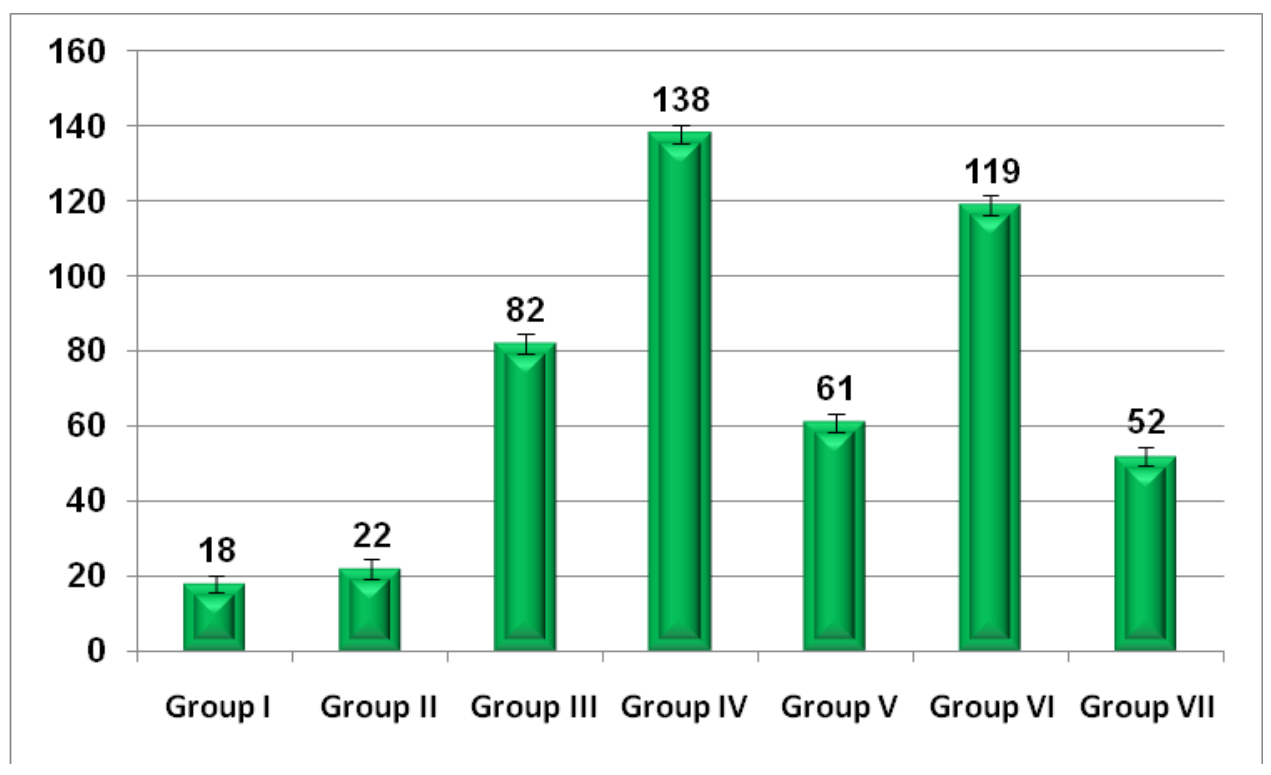

Graph.3 Mean serum IL 12P40 level (pg/dl) among the studied groups

\section{Immunohistochemical outcomes:}

The highest percent of CD4 +ve cells in liver was $60 \%$ in group IV (SEA+ DCs) followed by group VI (SWAP+ DCs) $50 \%$ in comparison with group II (control infected) the percent was $25 \%$ with the presence of highly statistically significant difference ( $\mathrm{p}<0.001)$ (Table 5\&Fig. 4). The mean H score of CD4 in liver was the highest $(170 \pm 9.12)$ in group IV (SEA+ DCs) which indicates strong expression of the stain followed by group VI 
(SWAP+DCs) $(140 \pm 8.81)$ versus $55 \pm 8.81$ in group II control infected with the presence of highly significant statistical difference ( $\mathrm{p}<0.001)$ (Table 6).DCs play a key role in the generation of $\mathrm{CD} 4 \mathrm{~T}$ cell responses to pathogens (Bizzell et al., 2018). DC-mediated tailoring of the appropriate $\mathrm{T}$ cell programme ensures a proper cascade of immune responses that adequately targets the insult (Eisenbarth, 2019).

\section{Antibodies profile}

The mean IgG level was the highest in group IV (SEA+ DCs) $1630 \pm 27.4 \mathrm{mg} / \mathrm{dl}$ followed by group VI (SWAP+DCs) $1410 \pm 24.0 \mathrm{mg} / \mathrm{dl}$ versus group I (control normal) 680.3 \pm 14.7 $\mathrm{mg} / \mathrm{dl}$ with the presence of highly statistically significant difference $(\mathrm{p}<0.001)(\mathrm{Graph} 1)$. DCs facilitate cross talk between the innate and adaptive immune system. Targeting vaccines to DCs thus provides a great deal of opportunities for influencing the humoral immune responses, by fine-tuning the $\mathrm{T}$ cell response as well as regulating antigen availability for B cells (Tesfaye, 2019). IgG is the dominant immunoglobulin evoked as the result of an immune response (Tete et al., 2013). It is known that Th2-type responses during helminthic infection can promote Bcell class switching to IgG1 (Harris and Gause, 2011). The increased IgG level recorded in the study suggests that there is an association between a reduction in worm burden and parasite-specific antibodies. These results were in agreement with that of Jinpinget al., (2004) whostated that there was increase in serum antibody level in mice immunized with SEA loading dendritic cell. And this indicated that SEA loading dendritic cell could induce protective immunity against infection of $S$. japonicum. The variation of IgG level results may be due to different Schistosoma species or different dose of infection. Moreover, Alves et al., (2018) and Ranasinghe et al., (2018) demonstrated that the protective vaccine formulation induced a specific IgG response in the vaccinated mice compared with their controls.

The present study supports the idea that both cellular and humoral immune mechanisms may be important to control $S$. mansoni infection. In the initial stages of a Schistosoma infection, parasites induce mainly a Th1-type immune response, and at around 6 weeks, at the commencement of female worm egg deposition, the immune response shifts dramatically to Th2 (Wilson et al., 2007).

\section{Cytokines profile, the mean IL-10 and IL- 12p40levels}

The highest mean level of IL-10 was in group IV (SEA+DCs) $(138 \pm 2.58 \mathrm{pg} / \mathrm{dl})$ followed by group VI (SWAP+DCs) (119 $\pm 4.08 \mathrm{pg} / \mathrm{dl})$ versus group I (control normal) $(18 \pm 2.31 \mathrm{pg} / \mathrm{dl})$ and group II (control infected) $(22 \pm 2.58 \mathrm{pg} / \mathrm{dl})$ with the presence of highly statistically significant difference $(\mathrm{p}<0.001)$. Moreover, there was a highly statistically significant difference between both combined groups; group IV (SEA + DCs) and group VI (SWAP + DCs) (Graph 2). Also, the mean IL$12 \mathrm{p} 40$ level was the highest in group IV (SEA+DCs) (122 $\pm 2.58 \mathrm{pg} / \mathrm{dl})$ followed by group VI (SWAP+ DCs) $(99 \pm 4.08 \mathrm{pg} / \mathrm{dl})$ versus group I (control normal) $(21 \pm 2.10 \mathrm{pg} / \mathrm{dl})$ and group II (control infected) $(26 \pm 2.58 \mathrm{pg} / \mathrm{dl})$ with the presence of a highly statistically significant difference $(p<0.001)$ (Graph 3).DCs have the ability to direct the profile of helper $\mathrm{T}(\mathrm{Th})$ cells towards Th1, Th2, Th17, Th9 and regulatory (Treg) cells (Perona et al., 2018). DCs are thought to play an important role in peripheral tolerance induction by various mechanisms, including production of soluble factors like IL-10, TGFor indoleamine 2,3-dioxygenase (Travis et al., 2007). IL-10 has also been shown to play an important role in schistosomiasis by 
preventing the development of Th1 and Th2mediated pathologies (Pearce and MacDonald, 2002). These results were supported by pervious other studies (Ricciardi et al., 2016, Alves et al., 2018, Egesaet al., 2018 and Ranasinghe et al., 2018). The vaccine that induces both Th1- and Th2-like responses would be necessary to achieve higher levels of protection. An additional concern is that a vaccine should not lead to a potentiated immunopathologic response, since the granulomatous reaction and resulting hepatic fibrosis in schistosomiasis are also immunologically mediated (Ribeiro De Jesus et al., 2000). Overall, the protection induced in the present study was probably the result of a balanced Th1/Th2 response.

\section{Ethical standards:}

The authors assert that all procedures contributing to this work complies with the ethical standards of the relevant national and institutional guides on the care and use of laboratory animals.

\section{Acknowledgment}

The authors sincerely thank drHala Gaber Metwaly, clinical pathology department, Faculty of medicine CairoUniversity. For her help in dendritic cells preparation. We are also grateful to dr Dina Mohamed Sweed, pathology department, Liver InstituteMenoufiaUniversity.For her effort during examination of pathological specimens.

\section{References}

Abdamelek, R., Al-Shennawi, E., and Mourad, S. 2014.Parasitological assessment of potential competitor immunizations in Schistosoma mansonicontaminated mice. African Journal of Parasitological Research 1, 028-034.

Alves, C.C., Araujo, N., Bernardes, W.P., dos
Mendes, M.M., Oliveira, S.C., and Fonseca, C.T. 2018. A strong humoral immune response induced by a vaccine formulation containing $\mathrm{rSm} 29$ adsorbed to Alum is associated with protection against Schistosoma mansoni reinfection in mice. Frontiers in Immunology 9, 2488. doi: 10.3389/fimmu.2018.02488.

Bergquist, N.R.2002. Schistosomiasis: from risk assessment to control. Trends in parasitology 18, 309-314.Doi 10.1016 / S1471-4922 (02) 02301-2.

Bizzell, E., Sia, J.K., Quezada, M., Enriquez, A., Georgieva, M., and Rengarajan, J. 2018.Deletion of BCGHip1protease enhances dendritic cell and CD4 T cell responses. Journal of leukocyte biology 103 , 739-748. https://doi.org/10.1002/JLB.4A0917363RR.

Boeckh, M., and Ljungman, P.2009. How we treat cytomegalovirus in hematopoietic cell transplant recipient. Blood 113, 5711-5719. https://doi.org/10.1182/blood-2008-10143560.

Bradford, M.M.1976. A rapid and sensitive method for the quantification of microgram quantities of protein utilizing the principle of protein dye binding. Analytical Biochemistry 72, 284-254. https: // doi.org/ 10.1016/0003-2697(76) 90527-3.

Cheever, A.W. 1970.Quantitative comparison of the intensity of Schistosoma mansoni infections in man and experimental animals. Transactions of the Royal Society of Tropical Medicine and Hygiene 63, 781-795. https://doi.org/10.1016/0035-9203 (69)90122-9.

Cheever, A.W., and Anderson, L.A. 1971. Rate of destruction of Schistosoma mansoni eggs in tissues of mice. The American Journal of Tropical Medicine 
and Hygiene20, 62-68. DOI: https:// doi.org/ 10.4269/ajtmh.1971.20.62.

Chitsulo, L., Loverde, P., and Engels, D. 2004.Schistosomiasis. Nature Reviews Microbiology 2, 12-13.doi: 10.1038/nrmicro801.

Colino, J., and Snapper, C.M. 2003. Dendritic cells, new tools for vaccination. Microbes and Infection 5, 311-319. https://doi.org/10.1016/S12864579(03)00033-9.

Constantino, J., Gomes, C., Falcão, A., Neves, B.M., and Cruz, M.T. 2017.Dendritic cell based immunotherapy: a basic review and recent advances. Immunologic Research 65, 798-810. DOI 10.1007/s12026-0178931-1.

Dunne, D.W., Richardson, B.A., Jones, F.M., Clark, M., Thorne, K.J., and Butterworth, A.E. 1993. The use of mouse/human chimaeric antibodies to investigate the roles of different antibody isotypes, including $\operatorname{IgA} 2$, in the killing of Schistosoma mansoni schistosomula by eosinophils.Parasite Immunology 15, 181-185. https://doi.org/10.1111/j.13653024.1993.tb00598.x.

Duval, D., Galinier, R., Mouahid, G., Toulza, E., Allienne, J.F., Portela, J., Calvayrac, C., Rognon, A., Arancibia, N., Mitta, G., Théron, A., and Benjamin, G. 2015. A Novel Bacterial Pathogen of Biomphalaria glabrata: A Potential Weapon for Schistosomiasis Control? PLoS Neglected Tropical Diseases 9, e0003489. https:// doi.org/10.1371/ journal.pntd.0003489.

Duvall, R.H., and Dewitt, W.B. 1967. An improved perfusion technique for recovering adult schistosomes from laboratory animals. American Journal of Tropical Medicine and Hygiene 16, 483-486.

DOI: https://doi.org/10.4269/ajtmh.1967.16.4
83.

Egesa, M., Lubyayi, L., Tukahebwa, E.M., Bagaya, B.S., Chalmers, I.W., Wilson, S., Hokke, C.H., Hoffmann, K.F., Dunne, D.W., Yazdanbakhsh, M., Labuda, L.A., and Cose, S. 2018. Schistosoma mansoni schistosomula antigens induce Th1//Pro-inflammatory cytokine responses. Parasite immunology, 40,e12592. https://doi.org/10.1111/pim.12592.

Eisenbarth, S.C. 2019. Dendritic cell subsets in $\mathrm{T}$ cell programming: location dictates function. Nature Reviews Immunology19, 89-103. https://doi.org/10.1038/s41577-0180088-1.

El-Ahwany, E., Bauiomy, I.R., Nagy, F., Zalat, R., Mahmoud, O., and Zada, S. 2012.T regulatory cell responses to immunization with a soluble egg antigen in Schistosoma mansoniinfected mice. The Korean Journal of Parasitology 50, 29-35. http://dx.doi.org/10.3347/kjp.2012.50.1. 29.

Etewa, S.E., Abd El-Aal, N.F., AbdelRahman, S.A., and El-Shafey, M.A. 2014.Parasitological evaluation of potential candidate vaccines in Schistosoma mansoni-infected mice. Journal of Parasitology and Vector Biology 6, 23-30. DOI: 10.5897/JPVB2013. 0142.

Etewa, S.E., Hegab, M.H.A., Metwally, A.S., Abd Allah, S.H., Shalaby, S.M., ElShal, A.S., Baredy, M., El Shafey, M.A. and Moawad, H.S.F. 2017.Murine hepatocytes DNA changes as an assessment of the immunogenicity of potential anti-schistosomal vaccines experimentally. Journal of Parasitic Diseases 41, 219-229.DOI 10.1007/s12639-016-0782-5.

García, F., Climent, N., Assoumou, L., Gil, C., González, N., Alcami, J., Leon, A., 
Romeu, J., Dalmau, J., MartinezPicado, J., Lifson, J., Autran, B., Costagliola, D., Clotet, B., Gatell, J.M., Plana, M., and Gallart, T. 2011.A therapeutic dendritic cell-based vaccine for HIV-1 infection. The Journal of Infectious Diseases 203, 473-478.https: // doi.org/ 10.1093/ infdis/ jiq077.

Hagan, P., Appleton, C.C., Coles, G.C., Kusel, J.R., and Tchuem-Tchuente, L.A. 2004. Schistosomiasis control: Keep taking the tablets. Trends in Parasitology 20, 92-97. https://doi.org/10.1016/j.pt.2003.11.010

Hald, S.M., Bremnes, R.M., Al-Shibli, K., Al -Saad, S., Andersen, S., Stenvold, H., Busund, L., and Donnem, T. 2013.CD 4/ CD 8 co -expression shows independent prognostic impact in resected non-small cell lung cancer patients treated with adjuvant radiotherapy. Lung Cancer 80, 209 215.

https://doi.org/10.1016/j.lungcan.2012.1 2.026 .

Harris, H.F. 1900.On the rapid conversion of haematoxylin into haematin staining reaction. Journal of Applied Microscopy and Laboratory Methods 3, 777.

Harris, N., and Gause, W.C. 2011.To B or not to $\mathrm{B}$ : B cells and the Th2-type immune response to helminths. Trends in Immunology 32, 80-88. DOI: 10.1016/j.it.2010.11.005.

Ismail, O.A. 2005.Study of the efficacy of adult worm, cercarial and egg antigens in protection against experimental intestinal schistosomiasis. MD thesis. Ismailia: Faculty of Medicine, Suez Canal University.

Jin-ping, L., Xi-gui, C., and Ding-wen, S. 2004. Study on the protective immunity of dendritic cells against infection of Schistosoma Japonicum. Journal of Xianning College Medical Science
2004-02.

Li, X.H., Cao, J.P., Tang, L.H., Xu, Y.X., Liu, S.X., et al., 2010. Protective efficacy induced by dendritic cells pulsed with GST in combination with $\mathrm{CpG}$ oligodeoxynucleotide against Schistosomajaponicum infection. Chinese Journal of Parasitology and Parasitic Diseases 28, 185-189. (PMID: 20806501).

Lopes Ida, C., Santos, V.R., Souza, V.L., and Rodrigues, I.R. 2006. Histopathological study of Schistosoma mansoniinfection in the murine model using the PC (Pará) and LILA Maranhão) strains. Memórias do Instituto Oswaldo Cruz 101, 273277. http://dx.doi.org/10.1590/S007402762006000900042.

Ma, L., Li, D., Yuan, C., Zhang, X., Ta, N., Zhao, X., Li, Y., and Feng, $X$. 2017.SjCRT, a recombinant Schistosoma japonicum calreticulin, induces maturation of dendritic cells and a Th1-polarized immune response in mice. Parasites and Vectors 10, 570. DOI 10.1186/s13071-017-2516-7.

Mahmoud, A.A.E., and Warren, K.S. 1974. Anti-inflammatory effects of tartar emetic and niridazole suppression of schistosome egg granuloma. Journal of Immunology112, 222-228.

McManus, D.P., and Loukas, A. 2008. Current status of vaccines for schistosomiasis. Clinical Microbiology Reviews 21, 225-242. DOI: 10.1128/CMR.00046-07.

Merrifield, M., Hotez, P.J., Beaumier, C.M., Gillespie, P., Strych, U., Hayward, T., and Bottazzi, M.E. 2016.Advancing a vaccine to prevent human schistosomiasis. Vaccine 34, 29882991. https:// doi.org/10.1016/ j.vaccine.2016.03.079.

Milner, T., Reilly, L., Nausch, N., Midzi, N., Mduluza, T., Maizels, R., and Mutapi, F. 2010.Circulating cytokine levels and 
antibody responses to human Schistosoma haematobium: IL-5 and IL10 levels depend upon ageand infection status. Parasite Immunology 32, 710 721. DOI: $\quad 10.1111 / \mathrm{j} .1365-$ 3024.2010.01235.x.

Morais, S.B., Figueiredo, B.C., Assis, N.R.G., Homan, J., Mambelli, F.S., Bicalho, R.O., Souza, C., Martins, V.P., Pinheiro, C.S., and Oliveira, S.C. 2018.SchistosomamansoniSmKI-1 or its c-terminal fragment induces partial protection against $S$. mansoni infection in mice. Frontiers in Immunology 9, 1762.doi: 10.3389/fimmu.2018.01762.

Nie, H., Zheng, Y., Li, R., Guo, T.B., He, D., Fang, L., Liu, X., Xiao, L., Chen, X., Wan, B., Chin, Y.E., and Zhang, J.Z. 2013. Phosphorylation of FOXP3 controls regulatory $\mathrm{T}$ cell function and is inhibited by $\mathrm{TNF}-\alpha$ in rheumatoid arthritis. Nature Medicine 19:322-328. 10.1038/nm.3085.

doi: $10.1038 / \mathrm{nm} .3085$.

Oliveira, C.R., Rezende, C.F., Silva, M.R., Borges, O.M., P^ego, A.P., and Goes, A.M. 2012. Oral vaccination based on DNA-Chitosan nanoparticles against Schistosoma mansoni Infection. The Scientific World Journal 2012, 1-11. doi:10.1100/2012/938457

Palucka, K., and Banchereau, J. 2013. Dendritic-cell-based therapeutic cancer vaccines. Immunity 39, 38-48. https:// doi.org/ 10.1016/ j.immuni.2013.07.004.

Pearce, E.J. 2005. Priming of the immune response by schistosome eggs. Parasite Immunology 27, 265-270.

Pearce, E.J., and MacDonald, A.S. 2002. The immunobiology of schistosomiasis. Nature Reviews Immunology 2, 499511. doi:10.1038/nri843.

Pellegrino, J., Oliveria, C.A., Faria, J., and Cunhan, A. 1962. New approach to the screening of drugs in experimental schistosomiasis mansoni in mice. American Journal of Tropical Medicine and Hygiene 11, 201-215. DOI: https://doi.org/10.4269/ajtmh.1962.11.2 01.

Perona, G., Thomaz, L.D., da Rosa, L.C., Thomé, R., and Verinaud, L.M. 2018. Modulation of dendritic cell by pathogen antigens: Where do we stand? Immunology Letters 196, 91-102.https: // doi.org/10.1016/ j.imlet.2018.02.001.

Ranasinghe, S.L., Duke, M., Harvie, M., and McManus, D.P. 2018.Kunitz-type protease inhibitor as a vaccine candidate against Schistosoma mansoni. International Journal of Infectious Diseases 66, 26-32. https://doi.org/10.1016/j.ijid.2017.10.02 4.

Ribeiro de Jesus, A., Araújo, I., Bacellar, O., Magalhães, A., Pearce, E., Harn, D. Strand, M., and Carvalho, E.M. 2000. Human immune responses to Schistosoma mansoni vaccine candidate antigens. Infection and Immunity 68, 2797-2803. $\quad$ DOI: 10. 1128/IAI.68.5.2797-2803.2000.

Ricciardi, A., Visitsunthorn, K., Dalton, J.P., and Ndao, M. 2016. A vaccine consisting of Schistosoma mansoni cathepsin B formulated in Montanide ISA 720 VG induces high level protection against murine schistosomiasis. BMC Infectious Diseases 16, 112. Doi. 10.1186/s12879016-1444-z.

Roy, R.M., and Klein, B.S. 2012.Dendritic cells in antifungal immunity and vaccine design. Cell Host and Microbe 11, 436-446. https:// doi.org/10.1016/j.chom.2012.04.005.

Selim, M.A., Ahmed, S.M., El Settawy, M.A., Abo El-Maaty, D.A., Abd El-Aal, N.F., and Abd El Hameed, E.F. 2016.Trials of vaccination by lung schistosomula and Biomphalaria alexandrina vaccines 
against experimental Schistosoma mansoni. Journal of Egyptian parasitologists united 9, 43-54. DOI: 10.4103/1687-7942.192996.

Stephenson, R., You, H., McManus, D.P., and Toth, I. 2014.Schistosome Vaccine Adjuvants in Preclinical and Clinical Research. Vaccines 2, 654-685. doi: 10.3390/vaccines2030654.

Tendler, M., Pinto, R.M., Oliveira, L.A., Gebara, G., and Katz, N. 1986. Schistosoma mansoni: vaccination with adult worm antigens. International Journal for Parasitology 16, 347-352.

Tesfaye, D.Y., Gudjonsson, A., Bogen, B., and Fossum, E. 2019. Targeting conventional dendritic cells to fine-tune antibody responses. Frontiers in Immunology 10, 1529. doi: 10.3389/fimmu.2019.01529.

Tete, S.M., Wilting, K.R., Horst, G., Klijn, M.A., Westra, J., de Haan, A., Huckriede, A.L.W., Kluin-Nelemans, H.C., Sahota, S.S., Bijl, M., and Bos, N. 2013.IgG antibody and TH1 immune responses to influenza vaccination negatively correlate with M-protein burden in monoclonal gammopathy of undetermined significance. Hematology and Leukemia 1(1). Doi: http://dx.doi.org/10.7243/2052-434X-25.
Toor, J., Alsallaq, R., Truscott, J.E., Turner, H.C., Werkman, M., Gurarie, D., King, C.H., and Anderson, R.M. 2018.Are we on our way to achieving the 2020 goals for schistosomiasis morbidity control using current world health organization guidelines? Clinical infectious diseases $66,245-252$. https://doi.org/10.1093/cid/ciy001.

Travis, M.A., Reizis, B., Melton, A.C., Masteller, E., Tang, Q., Proctor, J.M., Wang, Y., Bernstein, X., Huang, X., Reichardt, L.F., Bluestone, J.A., and Sheppard, D. 2007. Loss of integrin alpha (v) beta8 on dendritic cells causes autoimmunity and colitis in mice. Nature 449, $361 \quad-\quad 365$. doi:10.1038/nature06110.

WHO, 2017.Schistosomiasis: progress report 2001-2011, strategic plan 2012-2020. World Health Organization 2017; https ://www.who.int/ neglected_diseases/ resources/9789241503174/en.

Wilson, M.S., Mentink-Kane, M.M., Pesce, J.T., Ramalingam, T.R., Thompson, R., and Wynn, T.A. 2007. Immunopathology of schistosomiasis. Immunology and Cell Biology 85, 148154. https://doi.org/10.1038/sj.icb.7100014.

\section{How to cite this article:}

Amany F. Atia, Amera F. Afifi, Mohammed M. Abdel Gaffer, Nadia S. ELNahas, Mona F. Abdel-Samee Faheem and Salwa F. A. Oshiba. 2020. Dendritic Cells as an Adjuvant to some Schistosoma mansoni Antigens for Vaccination in Experimental Schistosomiasis. Int.J.Curr.Microbiol.App.Sci. 9(03): 32-53. doi: https://doi.org/10.20546/ijcmas.2020.903.005 